\title{
Detection of Parainfluenza Type 3 Virus Antigens in Goats
}

\author{
Adriana ANIȚĂ, Dragoş ANIȚĂ, Cristian RĂILEANU, Gheorghe SAVUȚA \\ Department of Public Health,University of Agricultural Sciences and Veterinary Medicine Iaşi, Romania \\ Corresponding author: epirovet@yahoo.com
}

Bulletin UASVM Veterinary Medicine 72(1) / 2015,

Print ISSN 1843-5270; Electronic ISSN 1843-5378

DOI:10.15835/buasvmcn-vm: 10385

\begin{abstract}
Parainfluenza-3 (PI-3) is the most common virus infection of the respiratory tract of sheep and goats throughout the world. The virus belongs to family Paramyxoviridae of order Mononegaviralis, the non-segmented negative single stranded RNA viruses. Often, infection is complicated by coinfection with respiratory bacteria (Mannheimia haemolytica). In this study, detection of PI-3 virus as causative agent of pneumonia in goat kids was investigated.

The virus was detected in lung tissues using direct immunofluorescence method (DFAT) with anti-PI-3 polyclonal antiserum conjugated to fluorescein isothiocyanate (VMRD, cat. no. CJ-F-PI3-10ML). The samples were collected from twelve diseased goat kids from a farm where were diagnosed respiratory signs.

The outbreak dynamics was characterized by high morbidity and mortality in goat kids aged between one to four weeks. Clinically all affected animals were presenting respiratory manifestation (coughing and nasal discharge). At the necropsy pneumonic apical and cardiac lobes in lungs were observed in all died goat kids. The positive result of DFAT was considered based on the specific fluorescence localized in the cytoplasm of bronchiolar epithelial cells.

In the present research work, we demonstrated the suitability of the immunodetection of viral antigens in routinely fixed tissue specimens as a diagnostic tool for PI-3 infection in goats.
\end{abstract}

Keywords: fluorescent antibody test, goat, parainfluenza type 3 virus.

\section{INTRODUCTION}

Respiratory tract diseases in goats cause major economic loses in goat industry throughout the world. Respiratory infections that commonly occur in sheep and goat often result from adverse physical and physiological stress combined with viral and bacterial infections. Goats are especially susceptible to parainfluenza type-3 virus (PI-3) and respiratory syncytial virus (RSV) (Yeşilbağ, 2009). More importantly these viruses also increase the susceptibility of sheep and goats to secondary Mannheimia haemolytica infection (Brogden, 1998). PI-3 virus can cause pneumonia by itself but more commonly is a part of the aetiological complex of enzootic pneumonia. The virus belongs to family Paramyxovoridae of order Mononegaviralis, the non-segmented negative single stranded RNA viruses.

The objective of this investigation was to determine the presence of PI-3 virus antigen using direct immunofluorescence in goat kids pneumonic lungs.

\section{MATERIAL AND METHODS}

The samples were collected from twelve diseased goat kids in a farm where respiratory signs were observed. The disease outbreak was characterized by high morbidity and mortality in goat kids aged between one to four weeks.

Direct immunofluorescence method (DFAT) was used for the detection of PI-3 antigen. The method was performed in lung tissues with interstitial or fibrinous bronchopneumonia. For this purpose polyclonal goat anti-PI-3 FITC (VMRD, cat.no. CJ-F-PI3-10ML) conjugate was used. Immunofluorescence staining was performed according to the manufacturer's procedure. Slide smears from lung tissues were dried at room temperature for 30 minutes. Then smears were fixed in acetone/methanol mixture for $20 \mathrm{~min}$ at 
room temperature. After drying the slides for 10 minutes in incubator, the smears were treated with the conjugate at $37^{\circ} \mathrm{C}$ in a humid chamber for 30 minutes. After washing with FA rinse buffer 1X (VMRD, cat.no.210-90-RB), the slides were mounted with FA mounting fluid (VMRD, cat.no.210-92-MF) prior to examining with a fluorescence microscope. FA Substrate Slides were used as positive and negative controls.(VMRD, cat. no. SLD-FAC-PI3).

\section{RESULTS AND DISCUSSION}

It has been reported that goat pneumonia can be determined by many factors including bacteria, viruses and stress factors which suppress the local defence mechanisms (Cashwell, 2007). Parainfluenza type-3 (PI-3) virus causes different clinical syndromes in sheep and goat especially respiratory infections (Obi, 1990). Serological surveys have shown that infection is widely spread among small ruminants population in many countries (Yener, 2005; Sendow, 2002; Lamontagne, 1985). In Romania first description of PI-3 infection in small ruminants was made by Pop et al. (1979).

The pathogenic role of PI- 3 virus in goats is similar to its role in cattle. PI- 3 virus affects the function of alveolar macrophages and destroys the cilia on the bronchial mucosa. This compromises the animal's natural clearance mechanism for removing pathogenic organisms from the respiratory tract and renders them susceptible to secondary bacterial infection (Yener, 2005).

PI-3 positive goat kids displayed the following clinical signs: pyrexia, coughing and

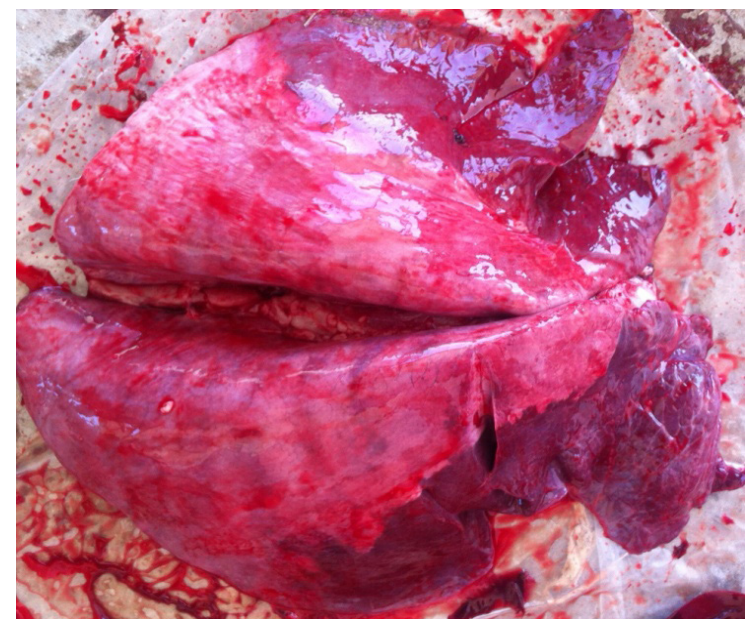

Fig. 1. Goat kid pneumonic lesions nasal discharge; the necropsy has shown area of pneumonia, particularly in apical and cardiac lobes. Pneumonic lesions characterized by patchy or confluent consolidated purple-red or grey

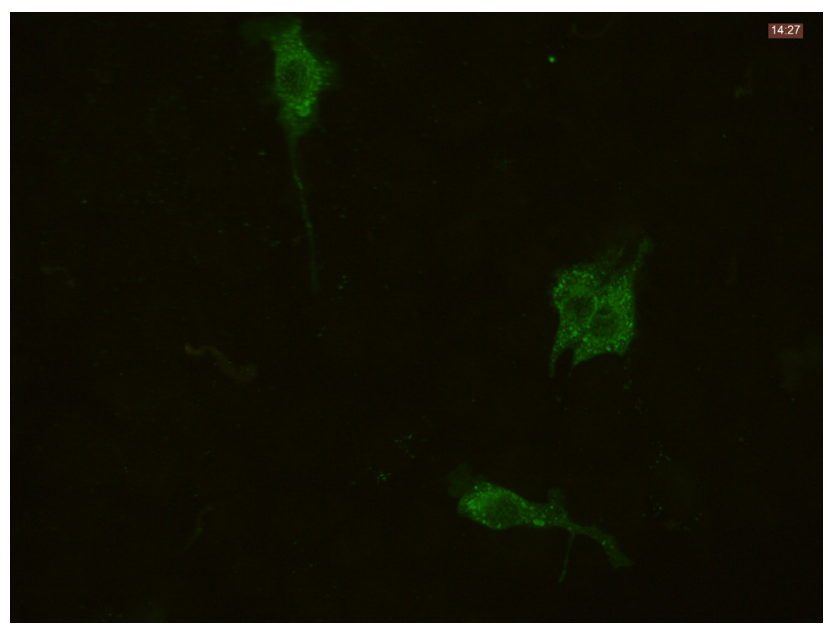

A

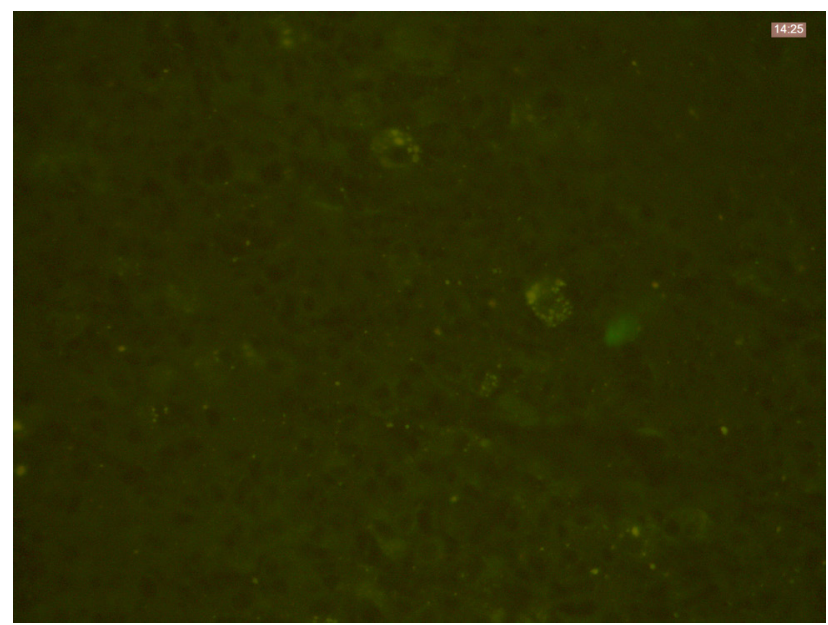

B

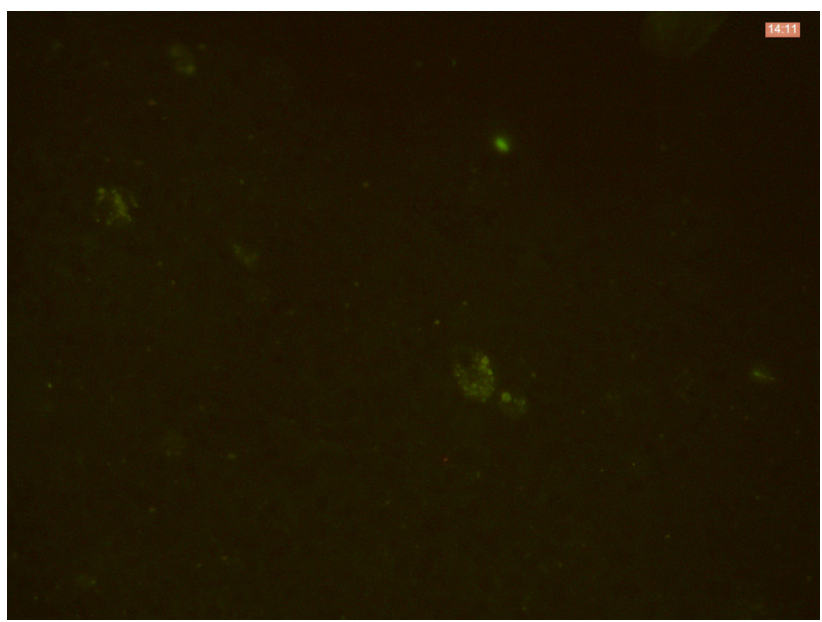

C

Fig. 2. PI-3 fluorescence staining in lung smears A. Positive control: MDBK cell line infected with PI-3, 400X B. and C. PI-3 virus positivity in goat kids lung by DFAT, 400X 
foci and irregular lobular foci of atelectasis were usually confined to the cranio-ventral regions of lungs.

Immunofluorescence staining was used for the determination of PI-3 antigen in lung smear samples. In previous studies, DFAT has successfully been used as a rapid diagnostic method for the diagnosis of PI-3 antigen (Gafer, 2009; Çeribasi, 2012). Fluorescent antibody technique (FAT) is an advantageous technique in terms of achieving rapid results because preparation and examination of the samples is made within short time.

In experimental PI-3 virus infection in calves and lambs, fluorescent foci were determined by DFAT widely in alveoli around the bronchoalveolar epithelium, these areas were referred to as starting points for histopathological changes (Stevenson, 1970). Similarly, in all examined lungs the fluorescent staining was detected in the cytoplasm. Specific fluorescence was seen in the form of granular perinuclear fluorescence. No fluorescence staining was detected in negative control section.

\section{CONCLUSIONS}

PI 3 infection is usually considered to be relatively mild and unnecessary to control. However the complications which may follow invasion by other organisms (usually bacteria) indicate that it is a virus of considerable economic importance. In the present research work, we tested the suitability of the immunodetection of viral antigens in routinely fixed tissue specimens as a diagnostic tool for PI-3 infection in goats. The results of this study demonstrate that PI-3 infection should be considered as a possible cause of pneumonia in goats, along with respiratory syncytial virus and bacterial infections (Mycoplasma and Mannhiemia species).

\section{REFERENCES}

1. Brogden KA, Lehmkuhl HD, Cutlip RC (1998). Pasteurella haemolytica complicated respiratory infections in sheep and goats. Vet Res 29(3-4):233-254.

2. Cashwell JL, Williams K (2007).The Respiratory System. In: Jubb KVF, Kennedy PC, Palmer N (eds.). Pathology of Domestic Animals, $5^{\text {th }}$, ed Maxie MG (eds). Saunders Elsevier, Edinburgh, UK, 594-622.

3. Çeribasi S, Özkaraca M, Özer H, Çeribasi AO (2012). Prevalence of parainfluenza type 3 virus antigens in pneumonic caprine lungs by direct immunofluorescence and immunoperoxidase techniques. Small Rum Res 108(1-3):127-132.

4. Gafer Jehan AM, Hussein HA, Reda IM (2009). Isolation and Characterization of PI-3 Virus from Sheep and Goats. IJV 5:28-35.

5. Lamontagne L, Descôteaux JP, Roy R (1985). Epizootiological survey of parainfluenza-3, reovirus-3, respiratory syncytial and infectious bovine rhinotracheitis viral antibodies in sheep and goat flocks in Quebec. Can J Comp Med Vet Sci 49(4):424-428

6. Obi TU, Ibu J (1990). Parainfluenza type 3 (PI-3) virus infection in goats in Nigeria, Small Rum Res 3:517-523.

7. Pop M, Vasiu C, Răpuntean G, Slavoici N, Cirstet I et al (1979). Serological survey of indigenous Romanian and imported sheep for parainfluenza-3 virus. Facultatea de Zootehnie și Medicina Veterinara, 145-149.

8. Sendow I, Syafriati T, Wiedosari E, Selleck P (2002). Infection of Parainfluenza type 3 (PI-3) as one of the causative agent of pneumonia in sheep and goats. IJAV $7(1): 62-68$.

9. Stevenson RG, Hore DE (1970). Comparative pathology of lambs and calves infected with parainfluenza type 3. J Com Path 80:613-618

10. Yener Z, Saglam YS, Timurkaan N, Ilhan F (2005). Immunohistochemical detection of parainfluenza type 3 virus antigens in paraffin sections of pneumonic caprine lungs. J Vet Med A Physiol Pathol Clin Med 52:268-271.

11. Yeşilbağ K, Güngör B (2009). Antibody prevalence against respiratory viruses in sheep and goats in North-Western Turkey. Trop Anim Health Prod 41(4):421-425. doi: 10.1007/s11250-008-9225-3. 